\title{
Turkish Myxomycetes developed in moist chamber cultures
}

\author{
MARJA HÄRKÖNEN and PERTTI UOTILA
}

\begin{abstract}
HÄRKÖNEN, M. \& UOTILA, P. 1983: Turkish Myxomycetes developed in moist chamber cultures. - Karstenia 23: 1 -9.

Bark collected from trees in 12 localities in West Turkey was used to establish 100 moist chamber cultures. The 116 Myxomycete specimens that emerged represented 30 species, none of which has been reported previously from Turkey, but almost all of which are known from adjacent countries. Three species could be determined to the genus only and possibly represent undescribed species. The morphological variation of some species is discussed, and the species composition is compared with that found by a similar method on plant material from North Europe and Gambia.
\end{abstract}

Marja Härkönen, Department of Botany, University of Helsinki, Unioninkatu 44, SF00170 Helsinki, Finland

Perti Uotila, Botanical Museum, University of Helsinki, Unioninkatu 44, SF-00170 Helsinki, Finland

\section{Foreword}

Botanical activities have greatly increased in Turkey during recent decades. However, studies on the cryptogams are still sporadic, and the few major projects are still in the initial stages (Tutel 1973). As regards the fungi, attention has been concentrated on the microfungi that cause plant diseases and on wood-inhabiting species. Myxomycetes is one of the neglected groups. To our knowledge, the works cited by Tutel (1973) include no reference to Myxomycetes, though at least one older and one recent contribution exist (Lohwag 1964, Sümer 1982). Even the myxomycete specimens from Turkey deposited in various herbaria are very scanty.

This study was intended to contribute some basic information on the myxomycete flora of Turkey. Extensive use was made of the account of the Greek Myxomycetes by Alexopoulos (1959) and several other studies from the Mediterranean area and adjacent countries are cited repeatedly on the following pages. Comparison has also been made with similar studies from Finland and North Norway (Härkönen 1977, 1978, 1981b, Härkönen \& Koponen 1978), and Gambia (Härkönen 1981a).

\section{Materials and methods}

The material was collected by the author Uotila, Mr. Arto Kurtto and Miss Kristiina Hormia during the botanical excursion to Western Anatolia in July 1981. Bark was taken from living and, in some cases, from dead trees at the following 12 localities (Fig. 1).
1. Al(A) Çanakale: Umurbey Çayi. Roadside on shrubby river bank, stem of a small solitary Pyrus communis L., July 22, Uotila 30421.

2. A2(A) Balikesir: Kuçenneti, NE of the Kuş Gölü, alt. ca $10 \mathrm{~m}$. Poplar wood, stem of tall Populus $X$ canadensis Moench, July 21, Uotila 30345.

3. A2(A) Istanbul: Kanlica, Anadolu Hisari. July 19.

a. Wooded brook ravine, stem of tall Cupressus sempervirens L., Uotila 30219.

b. Open low macchia shrubland, dead trunk of a deciduous tree (?Ceratonia siliqua L.), Uotila 30220.

4. A2(A) Istanbul: Kandilli, Sifa Suyu. Steep wooded slope, facing W, stem of almost dead Ceratonia siliqua L., July 19, Uotila 30201 b.

5. A3 Kocaeli (Izmit): on the road to Sapanca, ca. 20 $\mathrm{km}$ E of Izmit, Maş ukiye. Alt. ca. $40 \mathrm{~m}$, planted poplar forest, July 20.

a. Stem of Salix cf. alba L. on roadside, Uotila 30277.

b. Pole in a fence, probably of Populus, Uotila 30281, 30282.

c. Thick stem of an old Fraxinus cf. excelsior L., Uotila 30288b:

6. A3 Sakarya (Adapazari): Sapanca, Kumbaz, beach of the Sapanca Gölü. Alt. c. $40 \mathrm{~m}$, stem of planted Prunus, July 20, Uotila 30300.

7. B2 Denizli: Gökgöl, Gökgölü. Alt. ca. 840 m, yard of an abandoned tea house, stem of Salix, July 25 , Kurtto 3295, 3296.

8. C2 Denizli: Tekke Köy, ca. $5 \mathrm{~km} \mathrm{~S}$ of Denizli. Alt. $500 \mathrm{~m}$, steep slope with Pinus brutia wood, stem of Pinus brutia Ten., July 26, Uotila 30538. 
9. C2 Denizli: Cankurtaran village. Alt. $1150 \mathrm{~m}$, fairly open coniferous forest (Pinus nigra subsp. pallasiana, Juniperus spp.), July 26.

a. Stem and branches of Juniperus foetidissima Willd., Uotila 30558.

b. Stem and branches of Juniperus excelsa Bieb., Uotila 30561.

c. Twigs of Juniperus oxycedrus L., Uotila 30562.

d. Stem of Pinus nigra Arn. subsp. pallasiana (Lamb.) Holmboe, Uotila 30550.

e. Roadside in the village, stem of Robinia pseudacacia L., Hormia 642b.

10. Muğla: between Doğan and Köyceğiz, Fethiye junction, near sea level. Dry river bed, stem of an old Liquidambar orientalis Miller, July 27, Uotila 30607b. 11. C2 Muğla: between Gökova and Köyceğiz, near Toparlar Köyü, near sea level. Liquidambar orientalis forest, July 27.

a. Branches of Ficus carica L., Kurtto 3367b, 3380b.

b. Stem of Pinus brutia Ten., Kurtto 3376b.

c. Stem of Liquidambar orientalis Miller, Kurtto 3373.

12. C2 Muğla: Köyceğiz, Dalyan Boğaz mevkii. Sea level, beach with Pinus brutia, stem of Pinus brutia Ten., July 27, Uotila 30604.

In December 1981 the author Härkönen used the bark material to establish 100 moist chamber cultures, which were kept in an incubator at a temperature of $25 \pm 1^{\circ} \mathrm{C}$, illuminated artificially in a $12: 12 \mathrm{~h}$ light: dark cycle. The cultures were moistened with distilled water adjusted with $\mathrm{KOH}$ to $\mathrm{pH}$ 7. After two days the $\mathrm{pH}$ of the moisture in the dishes was measured with $\mathrm{pH}$ sticks (Merck Universalindikator). The moist chambers were then examined every second or third day under a dissecting microscope.

When developing Myxomycetes were found, the moist chambers were allowed to dry slowly and the Myxomycetes were then collected and provided with the collection number of Härkönen. After four weeks the remaining chambers were also dried for a week. All the chambers were then rewetted for another four-week period and examined as before.

The moist chambers yielded 116 specimens of Myxomycetes. These were identified by the author Härkönen, mainly by reference to Keller \& Brooks (1977), Lister (1925), Martin \& Alexopoulos (1969), Mitchell (1980), Nannenga-Bremekamp (1974) and Whitney (1980). When fructifications of a single species appeared twice in the same moist chamber culture, they were counted as one specimen. Representative specimens are deposited in $\mathrm{H}$.

Mrs. Hilkka Koponen took part in the survey. The microfungi (mostly Fungi imperfecti and Ascomycotina) which appeared in the Petri dishes were preserved for her future examination.

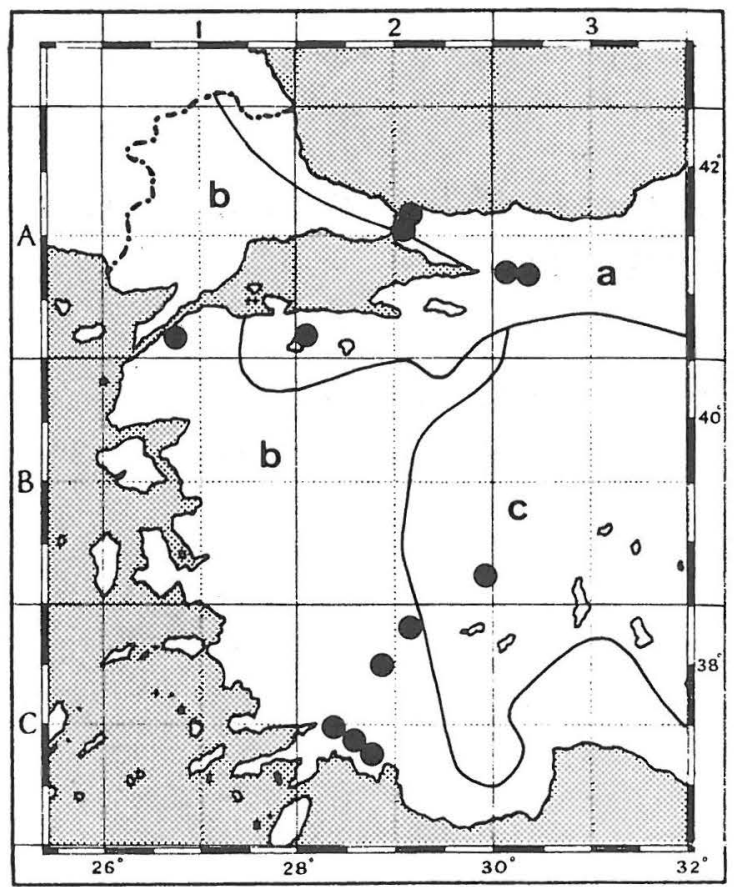

Fig. 1. Collecting sites in western Anatolia. Floristic areas from Davis (1969): a) Euro-Siberian, b) Mediterranean, c) Irano-Turanian.

\section{The species of Myxomycetes}

The 116 specimens obtained represent 30 species ( $\mathrm{Ta}$ ble 1). Three of them seem to be undescribed, but attempts to cultivate them from spore to spore were unsuccessful and they are not described here. Two of them, with scanty material, are excluded from the following discussion; the third, with abundant material, is discussed under Echinostelium sp.

In the following treatment of the species, the notes of the distribution in the Mediterranean area, in Romania, and in the adjacent southern USSR were compiled from Alexopoulos (1959), Almeida (1964, 1966, 1976, 1979), Brandza (1914, 1916, 1921, 1928), Faurel et al. (1965), Gràcia Barba $(1977,1979)$, Cràcia \& Llimona (1980), Gràcia et al. (1981, 1982), Lado \& Moreno $(1976,1978,1980,1981)$, Lado et al. (1980), Maire et al. (1926), Malençon \& Bertault (1967), Pidoplichka (1932), Pirola (1968), Pirola \& Credaro (1971, 1975), Rammeloo (1973), Ramon (1968), Vasjagina et al. (1977), Zerov (1967). The notes on the general distribution (merely whether a species is considered cosmopolitan or not) are from Martin \& Alexopoulos (1969).

Arcyria cinerea (Bull.) Pers.

This species appeared most frequently and on the greatest diversity of substrates in the moist chambers. Cosmopolitan. 
A. pomiformis (Leers) Rost.

Reported from Italy, the Iberian Peninsula, North Africa, Ukraine, Moldavia and Romania.

Badhamia affinis Rost.

Grey, sessile, discoid to short plasmodiocarpous fruit bodies umbilicate, depressed in the middle. Slender white capillitium typically badhamioid. Spores violaceous brown, minutely warted $11-12.3-16 \mu \mathrm{m}$ in diam. Reported from Greece, the Iberian Peninsula, North Africa, Kazakhstan and the Ukraine.

\section{B. foliicola A. Lister}

Sporangia crowded, sessile, globose to ellipsoid with constricted base, $0.2-0.7 \mathrm{~mm}$ in diam. Peridium thin, grey, iridescent with blue and golden tints. Capillitium clearly badhamioid, thin, yellowish. Spores light yellowish brown in transmitted light, 10-11.2$12 \mu \mathrm{m}$. Reported from the Iberian Peninsula, North Africa, Kazakhstan, the Ukraine, Moldavia and Romania.

B. panicea (Fries) Rost.

One scanty specimen. Reported from the Iberian Peninsula, North Africa, Moldavia, the Ukraine and Romania.

\section{B. versicolor A. Lister}

Seven specimens appeared with sessile grey or yellowish grey sporangia with a narrowed base. The diameter of the sporangia is $0.4-0.6 \mathrm{~mm}$ in all the specimens but one, in which the sporangia are $0.5-1 \mathrm{~mm}$ in diam. That specimen also has spores that are clearly oval and bigger $(9-10.7-13 \times 10-12-14.5 \mu \mathrm{m}$, Fig. 2) than those of the other specimens, which have only slightly adhering and slightly oval spores, 8$9.1-12.5 \mu \mathrm{m}$ in diam (Figs. 3-4). The biggest specimen also has more yellow-tinted peridium and capillitium than the others.

This agrees with what has been recognized as $B$. nitens Berk. According to the electron microscopic studies of Demaree and Kowalski (1975), however, $B$. nites has spores which are completely fused in clusters of 6 to 12 , and probably never separate in nature. $B$. versicolor is reported to form large, hollow spore clusters, which separate readily. In all our specimens the spores can be pressed apart from each other and there are also spines on the side of the spore which adheres to other spores. So, in spite of some difference in their size, shape and clusters, the spores all belong to spore type of $B$. versicolor. The capillitium also varies from typically badhamioid in the biggest sporangia to partially physaroid in the smallest ones.

Our attempts to obtain type materials for comparison resulted in only one authentic specimen of $B$. nitens, collected by Berkeley in Essex, England (K). That specimen contains only a piece of wood and no sporangia.

B. versicolor has been reported from Moldavia and the Ukraine.

Comatricha elegans (Racib.) G. Lister

Small (total height $0.7-1.3 \mathrm{~mm}$ ) but typical sporan-

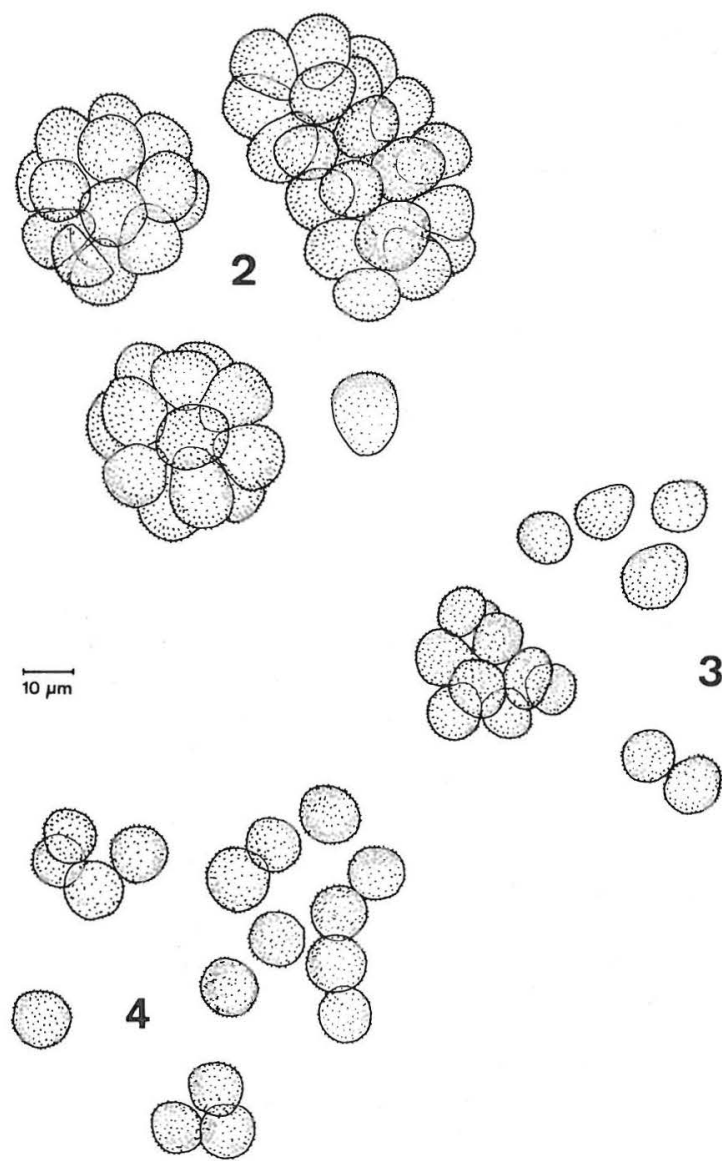

Figs. 2-4. Different sizes, shapes and clusters of spores of Badhamia versicolor, all from Loc. 7. - 2: No. 3013, 3: No. 3041, 4: No. 3064.

gia with very distinctive capillitium. Reported from Greece, Italy, the Iberian Peninsula, North Africa and Moldavia.

\section{C. laxa Rost.}

Coppery brown, black-stalked sporangia, $0.8-2.3$ $\mathrm{mm}$ in total height. The form of the sporangium head varies from globose to cylindric even in the same colony (Figs. 5-7), but all the sporangia have more or less horizontal primary branches in the capillitium. In transmitted light, the spores are greyish brown, very minutely warted, $7.5-8.6-9.5 \mu \mathrm{m}$ in diam.

Reported from Greece, the Iberian Peninsula, North Africa, the Ukraine, Moldavia and Romania.

C. nigra (Pers.) Schroet.

Cosmopolitan and evidently also common in the Mediterranean region.

\section{Cribraria violacea Rex.}

Typical, small (total height $0.5-0.9 \mathrm{~mm}$ ), dark purple sporangia. A cosmopolitan species. 
Diachea leucopodia (Bull.) Rost. Cosmopolitan.

Didymium quitense (Pat.) Torrend White, sessile, pulvinate, rounded or elongate sporangia, $0.2-0.5 \mathrm{~mm}$ in diam, up to $1 \mathrm{~mm}$ long. Outer peridium eggshell-like. Capillitium scanty, light-coloured. Spores dark brown, coarsely and unevenly warted; the warts partially in rows, $11-11.8-13 \mu \mathrm{m}$ in diam. Reported from the Iberian Peninsula.

D. squamulosum (Alb. \& Schw.) Fries Cosmopolitan and apparently also common in the study region.

Echinostelium colliculosum Whitney \& Keller Sporangia scattered to gregarious, stipitate, globose, bright pink, not fading. Head of sporangium 35-45 $\mu \mathrm{m}$ in diam, stipe $15-45 \mu \mathrm{m}$ long, containing granular material in the lower portion and tapering and becoming hyaline upwards. Columella more or less obscure: some sporangia have a small disc at the end of the stipe, some have a spore-like ball and some apparently have no columella at all. No capillitium or peridium can be seen. Spores smooth, hyaline in transmitted light, $9-10.5-12 \mu \mathrm{m}$ in diam, having only faint spore-to-spore articular surfaces (Fig 8).

According to Whitney (1980) found from Greece, Arizona, California and Nevada.

\section{E. minutum de Bary}

Sporangia scattered to gregarious, stipitate, white to pink. Head of sporangium $40-60 \mu \mathrm{m}$ in diam, the stipe $160-280 \mu \mathrm{m}$ in height, expanded and filled with granular material below, tapering and becoming hyaline above and usually ending in a small collar (Fig. 10). Capillitium a delicate branching system with pointed free ends. Some specimens have sporangia in which the capillitium is replaced by a spore-like cell (Fig. 11). As seen in Figs. 10 and 11, the specimens differ only in the form of the capillitium. The spores are hyaline in transmitted light, smooth, 5.5-7-9.5 $\mu \mathrm{m}$ in diam. Cosmopolitan.

\section{Echinostelium sp.}

Sporangia scattered to gregarious, stipitate, globose, dull pink. Head of sporangium $30-50 \mu \mathrm{m}$ in diam, stipe $100-180 \mu \mathrm{m}$ in height, containing granular material in the lower portion and tapering and becoming hyaline upwards. Columella globose, looking exactly like the spores of the species. No capillitium or peridium can be seen. Spores hyaline in transmitted light, 7.5-8.5-9 $\mu \mathrm{m}$ in diam, very minutely warted, bearing distinct circular thickenings at points of spore-tospore contact (Fig. 9). Whitney \& Keller (1980) state that Echinostelium colliculosum is chiefly characterized by minute, stipitate sporangia, a globose colu-

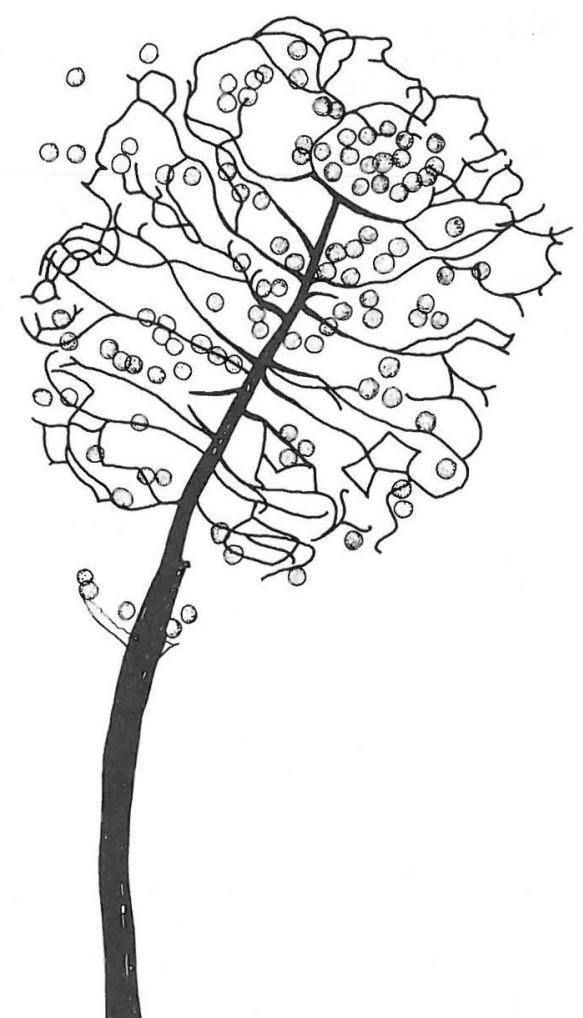

5

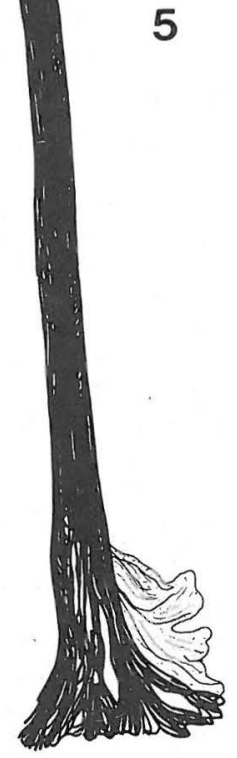

Figs. 5-7. The great diversity of sporangial size and shape in Comatricha laxa. All the figures drawn from the same group of sporangia (No. 3003), from Loc. 3b. 

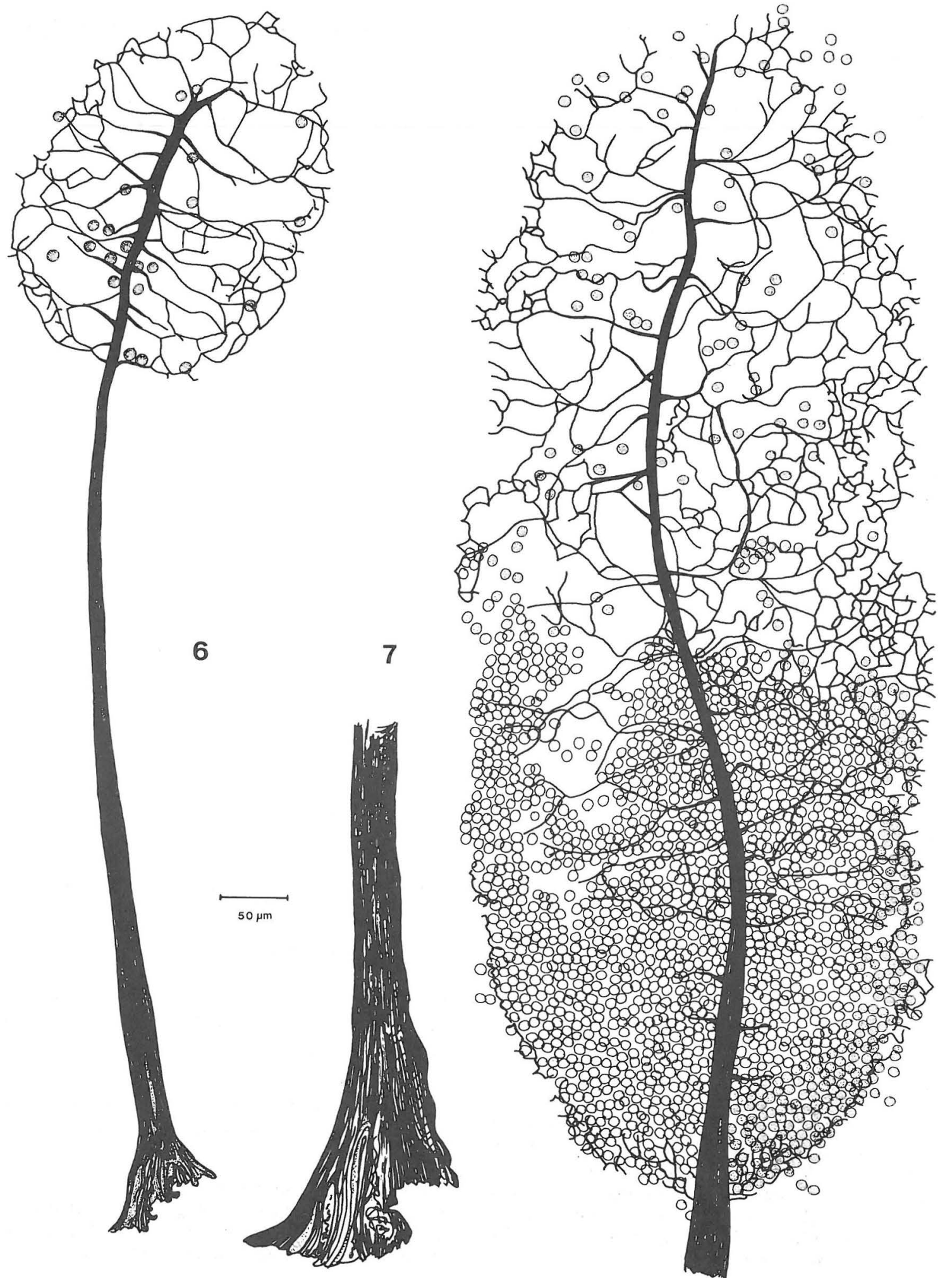

08808890
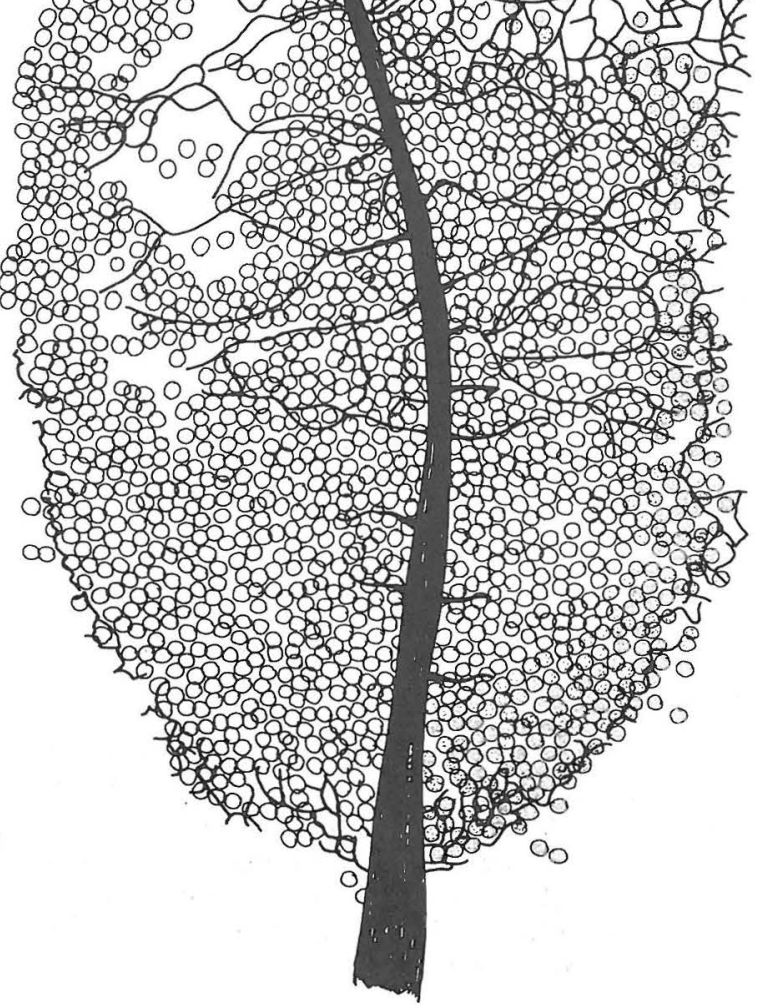
mella and the presence of thickened articular surfaces on the spores and upper surface of the columella. This fits with the present specimens, but they are too tall and the spores are too small for that species (Whitney 1980, for E. colliculosum: $70-150 \mu \mathrm{m}$ in height, spores $9-13 \mu \mathrm{m}$ in diam).

According to Alexopoulos (1958), who described E. elachiston from Greece, that species has spores only $6.5-8 \mu \mathrm{m}$ in diam. Whitney and Keller (1980) have examined the material of Alexopoulos and found that it also contains parts referable to $E$. colliculosum. Whitney (1980) writes: 'Collections identified as $E$. elachiston that have a globose sporelike columella are included with E. colliculosum.' This was done in spite of the spore size, which does not fit with the description of E. colliculosum. The present material may belong to a taxon originally included in the species concept of E. elachiston (Alexopoulos 1958) and later included in E. colliculosum by Whitney and Keller (1980). The geographical proximity of Greece and Turkey agrees with that possibility. The taxon still remains to be described.

Enerthenema papillatum (Pers.) Rost.

Scanty and aberrant specimens looking like those described in Nannenga-Bremekamp (1974) and Mitchell (1980). Reported from Greece, Italy, the Iberian Peninsula, North Africa, Moldavia and Romania.

Licea kleistobolus Martin

Small, coppery brown, sessile sporangia $0.7-0.2 \mathrm{~mm}$ in diam, dehiscing along a sunken preformed lid. Spores nearly colourless in transmitted light, having scattered groups of very fine warts, $10-10.5-11 \mu \mathrm{m}$ in diam. Reported from Greece and the Iberian Peninsula.

\section{L. denudescens Keller \& Brooks}

The specimens have a large amount of small scattered globose sporangia with a broad base, $0.1-0.2 \mathrm{~mm}$ in diam. The peridium, as seen in the binocular microscope, is thick, black, wrinkled and glossy, and there is no sign of a preformed lid. The inner peridium, as seen in transmitted light, is strongly papillate, as in Fig. 3 of Keller and Brooks (1977). In transmitted light the spores are smooth, pale olivaceous grey, globose or nearly so, with a sharply defined colourless area on one side and a thick wall on the opposite side, 8-9.5-11.5 $\mu \mathrm{m}$ in diam.

The specimens have much in common with Licea parasitica (Zukal) Martin, but they differ from it in the total absence of a lid in the sporangium, in the strongly papillate inner layer of the peridium, and in the size of the spores, which according to Martin and Alexopoulos (1969) is $11-13(-16) \mu \mathrm{m}$ in L. parasitica and according to Keller \& Brooks (1977) is 8.5$11 \mu \mathrm{m}$ in L. denudescens.
According to Keller \& Brook (1977) found from Spain.

Macbrideola cornea (G. Lister \& Gran) Alexop. Well-developed typical specimens. Reported from Greece, the Iberian Peninsula and North Africa.

Paradiacheopsis fimbriata (G. Lister \& Gran) Hertel One scanty but typical specimen. Reported from Greece, the Iberian Peninsula, Kazakhstan and the Ukraine.

Perichaena corticalis (Batsch) Rost.

Cosmopolitan.

\section{Physarum auriscalpium Cooke}

Scanty but well-developed specimens with stipitate and sessile sporangia. Reported from Greece, Italy, the Iberian Peninsula and North Africa.

\section{P. bitectum G. Lister}

Sessile, slightly compressed, thickly calcareous, greyish white plasmodiocarps, $0.4-0.8 \mathrm{~mm}$ in diam, up to $4 \mathrm{~mm}$ long. Capillitium with large, white nodes, which form a kind of pseudocolumella on the floor of the fruit bodies. Spores dark brown in mass, brown in transmitted light, rather sparsely and irregularly spiny, with thin, long spines 8-9.8-11 $\mu \mathrm{m}$ in diam.

The spore size fits better with $P$. bivalve Pers., but the irregularly spiny spore surface and the only slightly compressed plasmodiocarps without longitudinal dehiscense suggest $P$. bitectum. The plasmodium was brown, a colour which has not been mentioned for either of the species.

Reported from the Iberian Peninsula, North Africa, Israel, the Ukraine and Moldavia.

P. contextum (Pers.) Pers.

Pale yellow, thickly calcareous, sessile, small sporangia or reniform short aggregated plasmodiocarps up to $1 \mathrm{~mm}$ long. The specimen in somewhat prematurely dried, and so the dark purple-brown spores are uneven in size; the regular ones are $12-13 \mu \mathrm{m}$ in diam.

Reported from the Iberian Peninsula, North Africa, Israel, Kazakhstan, the Ukraine and Moldavia.

\section{Stemonitis flavogenita Jahn}

Reported from the Iberian Peninsula, Kazakhstan, the Ukraine, Moldavia and Romania.

\section{S. fusca Roth}

Cosmopolitan and evidently also common in the study area. Also collected in the field: Uotila 27420 \& A. Baytop (H).

Trichia contorta (Ditmar) Rost.

One small but typical sporangium. Reported from Greece, the Iberian Peninsula, North Africa, Kazakhstan, the Ukraine, Moldavia and Romania. 

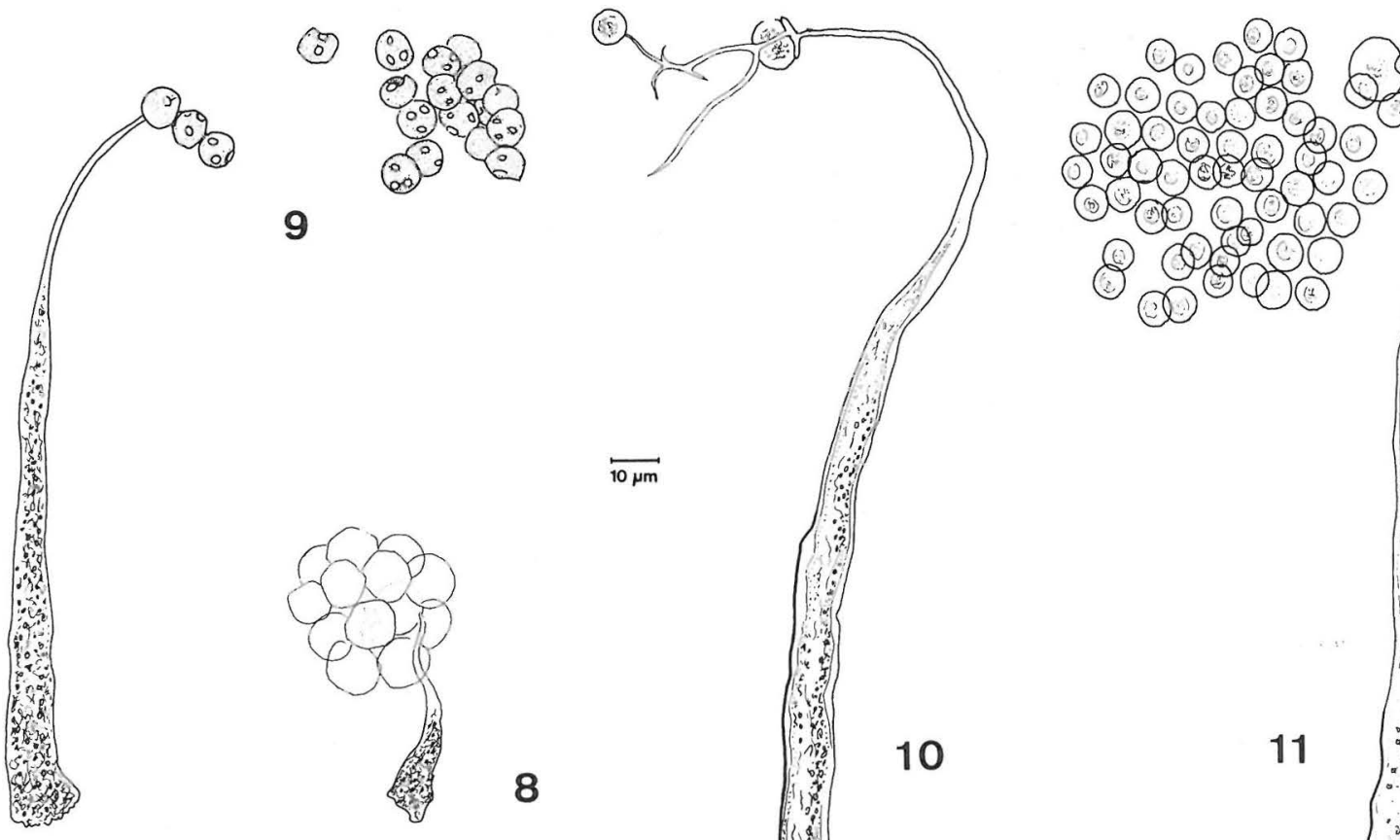

Figs. 8-11. Species of Echinostelium from Turkey. - 8: E colliculosum (No. 3014), from Loc. 9b. - 9: Echinostelium sp. with some resemblance to E. colliculosum (No. 3042), from Loc. 8. - 10: A typical sporangium of E. minutum (No. 3105), from Loc. 3b. - 11: E. minutum without a capillitium (No. 3116), from Loc. 11a.

\section{Discussion}

The ratio of the number of Myxomycete specimens (116) to the number of moist chambers (100) was $116 \%$. This is a much better emergence value than the results for moist chamber cultures made with material from the boreal zone (Finland and Norway, Härkönen 1977, 1978, 1981b, Härkönen \& Koponen 1978): with bark from living trees, ratio of Myxomycete specimens to the number of moist chambers was $45 \%$, with grain $11 \%$ and with tree litter $33 \%$. The result is also better than that obtained with material from Gambia in tropical Africa: $71 \%$ (Härkönen 1981a). The results for Turkey and Gambia are not fully comparable, however, because the Turkish material consisted only of tree bark, whereas the Gambian material comprised several kinds of plant remains. The bark of living trees usually yields more Myxomycetes and fewer competitive moulds than tree litter or the remains of herbaceous plants.

The number of species (30) is also high in proportion to the number of moist chambers. Of the 27 identified species seventeen have been found in Greece, 18 in Moldavia, 19 in the Ukraine and 25 on the Iberian Peninsula. The last-mentioned region seems to have been examined more intensively for Myxomycetes than other parts of the Mediterranean area.

The species common to the moist chamber material from Finland, Gambia and Turkey are: Arcyria cinerea, A. pomiformis, Comatricha elegans, Echinostelium minutum and Perichaena corticalis. Of these Arcyria cinerea, Perichaena corticalis and Echinostelium minutum are considered to be cosmopolitan (Martin \& Alexopoulos 1969).

Of the moist chambers, 51 were prepared with bark of coniferous trees and 49 with bark of deciduous trees. The Myxomycete specimens emerging on coniferous bark numbered 43 , these on deciduous bark 
Table 1. Myxomycete species obtained in moist chamber cultures prepared from Turkish bark material. For the symbols of localities, see pages $1-2$.

\begin{tabular}{|c|c|c|c|c|c|c|}
\hline & $\begin{array}{c}\text { Number } \\
\text { of } \\
\text { specimens }\end{array}$ & $\begin{array}{l}\text { Locality } \\
\text { and } \\
\text { host }\end{array}$ & $\begin{array}{r}\text { Host } \\
\text { coniferous }\end{array}$ & $\begin{array}{l}\text { tree } \\
\text { deciduous }\end{array}$ & $\begin{array}{l}\mathrm{pH} \text { of the } \\
\text { substrate }\end{array}$ & $\begin{array}{c}\text { Incubation } \\
\text { time in } \\
\text { days }\end{array}$ \\
\hline Arcyria cinerea & 14 & $3 b ; 5 b ; 6 ; 11 a ; 11 b$ & $\mathrm{x}$ & $\mathrm{x}$ & $4-5.5$ & $6-61$ \\
\hline A. pomiformis & 8 & $3 \mathrm{~b} ; 6$ & & $\mathrm{x}$ & $5-5.5$ & $6-41$ \\
\hline Badhamia affinis & 2 & $9 \mathrm{~d}, \mathrm{e}$ & $\mathrm{x}$ & $\mathrm{x}$ & 6 & $19-27$ \\
\hline B. foliicola & 9 & $5 b$ & & $\mathrm{x}$ & $4.5-5.5$ & $6-56$ \\
\hline B. panicea & 1 & 4 & & $\mathrm{x}$ & 6 & 15 \\
\hline B. versicolor & 7 & $7 ; 9 \mathrm{~b}$ & $\mathrm{x}$ & $\mathrm{x}$ & $6-7$ & $6-44$ \\
\hline Comatricha elegans & 6 & $3 a, b ; 4 ; 5 b$ & $\mathrm{x}$ & $\mathrm{x}$ & $4-5$ & $6-41$ \\
\hline C. laxa & 4 & $1 ; 3 \mathrm{~b} ; 8$ & $\mathrm{x}$ & $\mathrm{x}$ & $5-5.5$ & $3-20$ \\
\hline C. nigra & 1 & 1 & & $\mathrm{x}$ & 5.5 & 13 \\
\hline Cribraria violacea & 3 & $5 c ; 11 c$ & & $\mathrm{x}$ & 6 & $10-37$ \\
\hline Diachea leucopodia & 1 & $5 \mathrm{~b}$ & & $\mathrm{x}$ & 4 & 64 \\
\hline Didymium quitense & 3 & $9 b, c, d$ & $\mathrm{X}$ & & 6 & $18-30$ \\
\hline D. squamulosum & 1 & 2 & & $\mathrm{x}$ & 6 & 50 \\
\hline Didymium sp. & 2 & 1 & & $\mathrm{x}$ & 5.5 & $13-18$ \\
\hline Echinostelium colliculosum & 5 & $9 \mathrm{~b}, \mathrm{~d}$ & $\mathrm{X}$ & & $5.5-6$ & $6-8$ \\
\hline E. minutum & 10 & $3 \mathrm{~b}: 9 \mathrm{~d}: 11 \mathrm{a}, \mathrm{c} ; 12 \mathrm{c}$ & $\mathrm{x}$ & $\mathrm{x}$ & $5-6$ & $6-41$ \\
\hline E. sp. & 8 & $8 ; 12$ & $\mathrm{x}$ & & 5.5 & $8-34$ \\
\hline Enerthenema papillatum & 3 & $3 a ; 7 ; 11 c$ & $\mathrm{x}$ & $\mathrm{x}$ & $4-6$ & $6-20$ \\
\hline Licea kleistobolus & 2 & $5 \mathrm{~b} ; 11 \mathrm{a}$ & & $\mathrm{x}$ & $4.5-5$ & 13 \\
\hline L. denudescens & 4 & $12 \mathrm{c}$ & $\mathrm{x}$ & & 5.5 & $14-37$ \\
\hline Macbrideola cornea & 5 & $5 c ; 9 d$ & $\mathrm{x}$ & $\mathrm{x}$ & $5.5-6$ & $6-17$ \\
\hline Paradiacheopsis fimbriata & 1 & 4 & & $\mathrm{x}$ & 4 & 6 \\
\hline Perichaena corticalis & 7 & $5 c ; 9 a, d, e$ & $\mathrm{x}$ & $\mathrm{x}$ & $5.5-6$ & $7-49$ \\
\hline Physarum auriscalpium & 2 & $9 \mathrm{~d}$ & $\mathrm{x}$ & & 5.5 & $49-56$ \\
\hline P. bitectum & 2 & 6 & & $\mathrm{x}$ & 5 & $21-33$ \\
\hline P. contextum & 1 & $5 c$ & & $\mathrm{x}$ & 6 & 8 \\
\hline$P . \mathrm{sp}$. & 1 & 7 & & $\mathrm{x}$ & 7 & 6 \\
\hline Stemonitis flavogenita & 1 & $9 d$ & $\mathrm{X}$ & & 5 & 60 \\
\hline S. fusca & 1 & $5 b$ & & $\mathrm{x}$ & 5 & 30 \\
\hline Trichia contorta & 1 & 8 & $\mathrm{x}$ & & 5.5 & 56 \\
\hline
\end{tabular}

73. The ratio of the number of specimens to the number of moist chambers was thus $84 \%$ for coniferous and $149 \%$ for deciduous bark. The coniferous bark produced 16 species of Myxomycetes and the deciduous bark as many as 23 species. So the deciduous bark seemed to be more favourable for Myxomycetes than the bark of conifers. Such a trend was not evident in moist chamber cultures made with material from Finland and northern Norway (Härkönen 1977, 1978), one reason being the especially low productivity of Betula bark, which formed a great part of the material in these northern studies.

\section{Myxomycetes collected in field}

During the excursion in 1981 only one Myxomycete specimen was collected in the field. It was Stemonitis splendens Rost., from A3 Sakarya (Adapazari): Sapanca, Kumbaz, alt. c. $40 \mathrm{~m}$, shrubland near the sho- re of the Sapanca Gölü, trunk of Prunus sp., July 20, 1981 A.Kurtto $3112(\mathrm{H})$. A specimen of Stemonitis fusca was collected earlier: A3 Sakarya (Adapazari): N. side of the Sapanca Gölü, Eşme - Esentepe, shore of the lake, at base of a deciduous tree, July 13, 1978 P.Uotila 27420 \& A. Baytop (H). Both are cosmopolitan in their distribution.

Lycogala epidendrum (L.) Fries was reported from Turkey by Lohwag (1964) and Amaurochaete atra (Alb. \& Schw.) Rost. (syn. A. fuliginosa (Sow.) Macbr.) by Sümer (1982). Consequently, the list of Myxomycetes known from Turkey now contains 31 species.

Acknowledgements. The following persons have been consulted: Bruce Ing (Great Britain), Harold Keller (U.S.A.), David Mitchell (Great Britain), N.E. Nannenga-Bremekamp (The Netherlands), Sabri Sümer (Turkey), Kenneth Whitney (U.S.A.), and the curators of the herbaria BM, E and K. We want to thank all of them for their valuable contribution, which helped us to reach some conclusion in the unexpectedly difficult task of identification. 


\section{References}

Alexopoulos, C.J. 1958: Three new species of Myxomycetes from Greece. - Mycologia 50: 52-56.

- 1959: Myxomycetes from Greece. - Brittonia 11: 2540.

Almeida, M.G. 1964: Contribuição para o estudo dos Myxomycetes de Portugal. - Bol. Soc. Portuguesa Ciênc. Nat. $2^{\mathrm{a}}$ sér. 10: 172-185.

- 1966: Contribuição para o estudo dos Myxomycetes de Portugal 2. - Rev. Fac. Ciências Lisboa $2^{\text {a }}$ sér. C. 14: $5-12$.

- 1976: Contribuição para o estudo dos Myxomycetes de Portugal 4. - Rev. Biol. 10: 113-125.

- 1979: Contribuição para o estudo dos Myxomycetes de Portugal 5. - Rev. Biol. 11: 79-90.

Brandza, M. 1914: Myxomycètes de Roumanie. - Ann. Sci. Univ. Jassy 8: 259-294.

- 1916: Note sur quelques Myxomycètes nouvelles pour la flore Mycologique de la Roumanie. - Ann. Sci. Univ. Jassy 10: 182-199, 2 pls.

- 1921: Troisième contribution a l'etude des Myxomycètes de Roumanie. - Ann. Sci. Univ. Jassy 11: 113-131.

- 1928: Les Myxomycètes de Neamtz (Moldavie). - Bull. Soc. Mycol. France 44: 249-299, 4 pls.

Davis, P.H. 1971: Distribution patterns in Anatolia with particular reference to endemism. - In: Davis, P.H. et al. (eds.), Plant life of South-West Asia: 15-26. Aberdeen.

Demaree, R.S. \& Kowalski, D.T. 1975: Fine structure of five species of Myxomycetes with clustered spores. - J. Protozool. 22(1): 85-88.

Faurel, L., Feldmann, J. \& Schotter, G. 1965: Catalogue des Myxomycètes de l'Afrique du Nord. - Bull. Soc. Hist. Nat. Afr. Nord 55: 9-35.

Gràcia Barba, E. 1977: Contribucion a la flora de mixomicetes de Cataluna - Mediterranea 2: 79-87.

- 1979: Contribució al coneixement de la flora i distribució dels mixomicets a la Mediterrània occidental 1: Eivissa i Formentera (Pitiüses). - Folia Bot. Misc. Barcelona 1: $37-44$

Gràcia E., Honrubia, M. \& Ladó, C. 1982: Mixomicets nous o interessants per a la flora Ibèrica i Balear. - Folia Bot. Misc. Barcelona 3: 95-99.

Gràcia, E., Honrubia, M. \& Llimona, X. 1981: Aportación al conocimiento de los hongos del SE de Espana 2. Mixomicetes de la provincia del Albacete. - Anales Univ. Murcia, Ciencias 37: 63-79.

Gràcia, E. \& Llimona, X. 1980: Contribución al conocimiento de la flora y distribución de los mixomicetes en el Mediterráneo occidental 3. Sureste de Espana: Murcia. - Anales Univ. Murcia, Ciencias 34: 3-21.

Härkönen, M. 1977: Corticolous Myxomycetes in three different habitats in southern Finland. - Karstenia 17: $19-32$.

- 1978: On corticolous Myxomycetes in northern Finland and Norway. - Ann. Bot. Fennici 15: 32-37.

- 1981a: Gambian Myxomycetes developed in moist chamber cultures. - Karstenia 21: 21-25.

- 1981b: Myxomycetes developed on litter of common Finnish trees in moist chamber cultures. - Nordic J. Bot. 1: 791-794.

Härkönen, M. \& Koponen, H. 1978: Myxomycetes developed on grain in moist chamber cultures. - Karstenia 18. $58-62$.
Keller, H.W. \& Brooks, T.E. 1977: Corticolous Myxomycetes 7: Contribution toward a monograph of Licea, five new species. - Mycologia 69: 667-684.

Ladó, C. \& Moreno, G. 1976: Contribución al estudio de los Myxomycetes en España peninsular 1. - Anales Inst. Bot. Cavanilles 33: 111-124.

- 1978: Contributión al estudio de los Myxomycetes en España peninsular 2. - Anales Inst. Bot. Cavanilles 34: $401-415$.

- 1980: Contributión al estudio de los Myxomycetes en España peninsular 3. Provincia de Madrid. - Anales Jardin Bot. Madrid 37: 5-30.

- 1981: Contributión al estudio de los Myxomycetes en la peninsula Iberica 4. Pais Vasco. - Munibe 33: 63-78.

Ladó, C., Moreno, G., Ortega, A. \& Calonge, F.D. 1980: Estudios sobre Myxomycetes 4. Provincia de Granada. - Bol. Soc. Micol. Cast. 5: 55-68.

Lister, A. 1925: A monograph of the Mycetozoa. 3rd ed. rev. by G. Lister. - 286 pp., 222 pls. London.

Lohwag, K. 1964: Belgrad ormanindan mikolojik notlar. Istanbul Úniv. Orman Fak. Dergisi Ser. B 14: 128-135.

Maire, R., Patouillard, N. \& Pinoy, E. 1926: Myxomycètes de l'Afrique du Nord. - Bull. Soc. Hist. Nat. Afr. Nord 17: $38-43$.

Malençon, G. \& Bertault, R. 1967: Champignons, du Maroc. - Bull. Soc. Sci. Nat. Phys. Maroc 47: 237-281.

Martin, G.W. \& Alexopoulos, C.J. 1969: The Myxomycetes. $-560 \mathrm{pp}$. Iowa City.

Mitchell, D.W. 1980: A key to the corticolous Myxomycetes. -63 pp. Cambridge

Nannenga-Bremekamp, N.E. 1974: De Nederlandse Myxomyceten. $-440 \mathrm{pp}$. Zutphen

Pidoplichka, M. 1932: Kritichni materijali do flori miksomitsetiv Ukraini. (Résumé: Sur la flore des myxomycétes de l'Ukraine.) - Zhurn. Bio-bot. Tsiklu VUAN 3-4: 69102.

Pirola, A. 1968: Una lista di mixomiceti Italiani. — Giornale Bot. Italiano 102: $21-32$.

Pirola, A. \& Credaro, V. 1971: Contributo alla flora Mixomicetologica Italiana. - Giornale Bot. Italiano 105: 157-165.

- 1975: Tentativo di inquadramento sinecologico di mixomiceti italiani. - Not. Fitosoc. 10: 111-130.

Rammeloo, J. 1973: Contribution à la connaissance des Myxomycètes du Maroc (lre not). - Bull. Soc. Sci. Nat. Phys. Maroc 53: 31-35.

Ramon, E. 1968: Myxomycetes of Israel. - Israel J. Bot. 17: $207-211$.

Sümer, S. 1982: Bati karadeniz bölgesi, özellikle Bolu çevresinde bulunan odun thripçisi mantarlar. (Summary: Wood-decaying fungi in the western Black Sea region of Turkey, especially in and around Bolu province.) - Istanbul Orman Fak. Yayinlari 312: 1-194.

Tutel, B. 1973: Cryptogamic flora of Turkey. - Istanbul Univ. Orman Fak. Yayinlari 209: 223-238.

Vasjagina, M.P., Byzova, Z.M. \& Golovenko, I.N. 1977: Nizshie griby i miksomitsety (Phycomycetes et Myxomycetes). - Flora sporovykh rastenii Kazakhstana 10: 1-348. Alma-Ata.

Whitney, K.D. 1980: The Myxomycete genus Echinostelium. - Mycologia 72: 950-987.

Whitney, K.D. \& Keller, H.W. 1980: A new species of Echinostelium. - Mycologia 72: 640-643.

Zerov, D.K. (ed.) 1967: Viznachnik gribiv Ukraini 1.-254 pp. Kiev.

Accepted for publication

on April 19, 1983 